\title{
UJI BIOAKTIVITAS METABOLIT SEKUNDER FUNGI YANG BERASOSIASI DENGAN Aaptos suberitoides ASAL TANJUNG PECARON SITUBONDO
}

\author{
Syarmalina, Syamsudin, dan Meysa I.P \\ Fakultas Farmasi Universitas Pancasila \\ Srengseng Sawah Jagakarsa Jakarta 12640 Indonesia \\ Email : enae4_dpk@yahoo.co.id
}

\begin{abstract}
ABSTRAK
Aaptos suberitoides merupakan salah satu komponen biota penyusun terumbu karang yang mempunyai potensi bioaktif yang belum banyak dimanfaatkan. Hewan laut ini mengandung senyawa aktif yang persentase keaktifannya lebih besar dibandingkan dengan senyawa-senyawa yang dihasilkan oleh tumbuhan darat, sehingga dilakukan penelitian yang bertujuan untuk mengisolasi fungi yang berasosiasi dengan Aaptos suberitoides yang dapat menghasilkan metabolit sekunder sesuai dengan metabolit yang dihasilkan oleh Aaptos suberitoides menggunakan metode direct seed dan pour plate. Hasil yang didapat dari direct seed berjumlah 3 isolat sedangkan dari pour plate berjumlah 5 isolat, sehingga isolat berjumlah 8 (delapan). Uji aktivitas antimikroba terhadap supernatan hasil fermentasi goyang dari 8 (delapan) isolat menggunakan starter $10 \%$ dan 50\% dengan DDH berkisar antara 6,67 mm - 9,67 mm untuk mikroba uji bakteri dan 6,88 mm - 13,42 mm untuk mikroba uji fungi, sedangkan untuk hasil uji BSLT nilai $\mathrm{LC}_{50}$ menggunakan starter $10 \%$ berkisar antara $518,192 \mu \mathrm{g} / \mathrm{mL}-913,901 \mu \mathrm{g} / \mathrm{mL}$ dan starter $50 \%$ berkisar antara $333,960 \mu \mathrm{g} / \mathrm{mL}-787,360 \mu \mathrm{g} / \mathrm{mL}$. dengan demikian dapat disimpulkan bahwa hasil uji antimikroba antara supernatan hasil fermentasi goyang memiliki DDH yang lebih besar dibandingkan dengan DDH setelah ekstraksi, sedangkan hasil uji BSLT supernatan hasil fermentasi goyang lebih besar nilai $\mathrm{LC}_{50}$ dibandingkan dengan setelah ekstraksi.
\end{abstract}

Kata kunci : Bioaktivitas, metabolit sekunder, spons Aaptos suberitoides, Tanjung pecaron

\begin{abstract}
Sponges, an important part of the coral reef ecosystem, have a bioactive potential that have not been widely used. Sponges compound an active substances with higher percentage than other which produced by land plants, so in this research aims to isolate the fungi that associated with Aaptos suberitoides which generate secondary metabolit derived from Aaptos suberitoides, using direct seed and pour plate methods. Three isolates produced by direct seed method and five isolated derived from pour plate method, the total was eight isolates. Antimicrobial activity for supernatants from shake fermentation of eight isolates using starter $10 \%$ and 50\% have shown DDH ranges $6,67 \mathrm{~mm}-9,67 \mathrm{~mm}$ for microbial test of bacteria and $6,88 \mathrm{~mm}-13,42 \mathrm{~mm}$ for microbial test of fungi. While tests on BSLT, indicated by LC50 values, using starter 10\% were within the range of 518,192 $\mu \mathrm{g} / \mathrm{mL}-913,901 \mu \mathrm{g} / \mathrm{mL}$ and using starter $50 \%$ were in the range of $333,960 \mu \mathrm{g} / \mathrm{mL}-$
\end{abstract}


$787,360 \mu \mathrm{g} / \mathrm{mL}$. In sum, result of antimicrobial test from supernatants derived from shake fermentation has a higher DDH than DDH resulted from extraction. The similar result also produced from of BSLT test that showed supernatants with shake fermentation has a higher LC50 values than after extraction.

Keywords : Bioactivity, secondary metabolite, sponges Aaptos suberitoides, Tanjung pecaron

\section{PENDAHULUAN}

Spons merupakan salah satu komponen biota penyusun terumbu karang yang mempunyai potensi bioaktif yang belum banyak di manfaatkan. Penelitian ini bertujuan untuk mengisolasi fungi yang berasosiasi dengan Aaptos suberitoides yang dapat menghasilkan metabolit sekunder sesuai dengan metabolit yang dihasilkan oleh Aaptos suberitoides menggunakan metode direct seed dan pour plate.

\section{METODE}

Metode awal adalah isolasi dengan metode direct seed dan pour plate. Isolat murni hasil isolasi difermentasi goyang sehingga didapat supernatan. Supernatan hasil fermentasi dan ekstrak hasil partisi dari supernatan diuji antimikroba dan Toksisitas nya dengan Metoda BSLT. Ekstraksi dilakukan menggunakan pelarut (polar, semipolar, non polar).

\section{A. Uji Aktivitas Antimikroba}

Uji Aktifitas Antimikroba menggunakan metode Diffusi agar dengan menggunakan pecadang kertas cakram. Hasil uji yang terlihat adalah dengan menghitung Diameter Daerah Hambat yang terbentuk disekeliling kertas Cakram ebagai pecadang.

\section{B. Uji Aktivitas Secara BSLT}

Timbang saksama lebih kurang $50 \mathrm{mg}$ ekstrak sampel, kemudian larutkan dalam pelarut yang sesuai sampai 5,0 mL. Dipipet masing-masing sebanyak $500 \mu \mathrm{L}, 50 \mu \mathrm{L}, 5 \mu \mathrm{L}$. Masukkan ke dalam vial, kemudian diuapkan sampai kering. Tambahkan masing masing $\pm 3 \mathrm{~mL}$ air laut dan masukkan masing-masing 10 ekor nauplii, tambahkan air laut sampai $5 \mathrm{~mL}$. Lakukan tiga kali pengulangan. Setelah 24 jam, jumlah larva yang mati dihitung untuk mendapatkan nilai $\mathrm{LC}_{50}$.

\section{ALAT DAN BAHAN}

Alat-alat gelas, lampu TL 18 Watt, wadah penetasan, Erlenmeyer, $L A F$, tabung reaksi, vial, waterbath, cawan petri. Fungi hasil isolasi dari spons Aaptos suberitoides, air laut buatan, PDA, PDB, SDA, SDB, PDY, NA, n-heksan pro analisis, etil asetat pro analisis. 


\section{SKEMA KERJA}

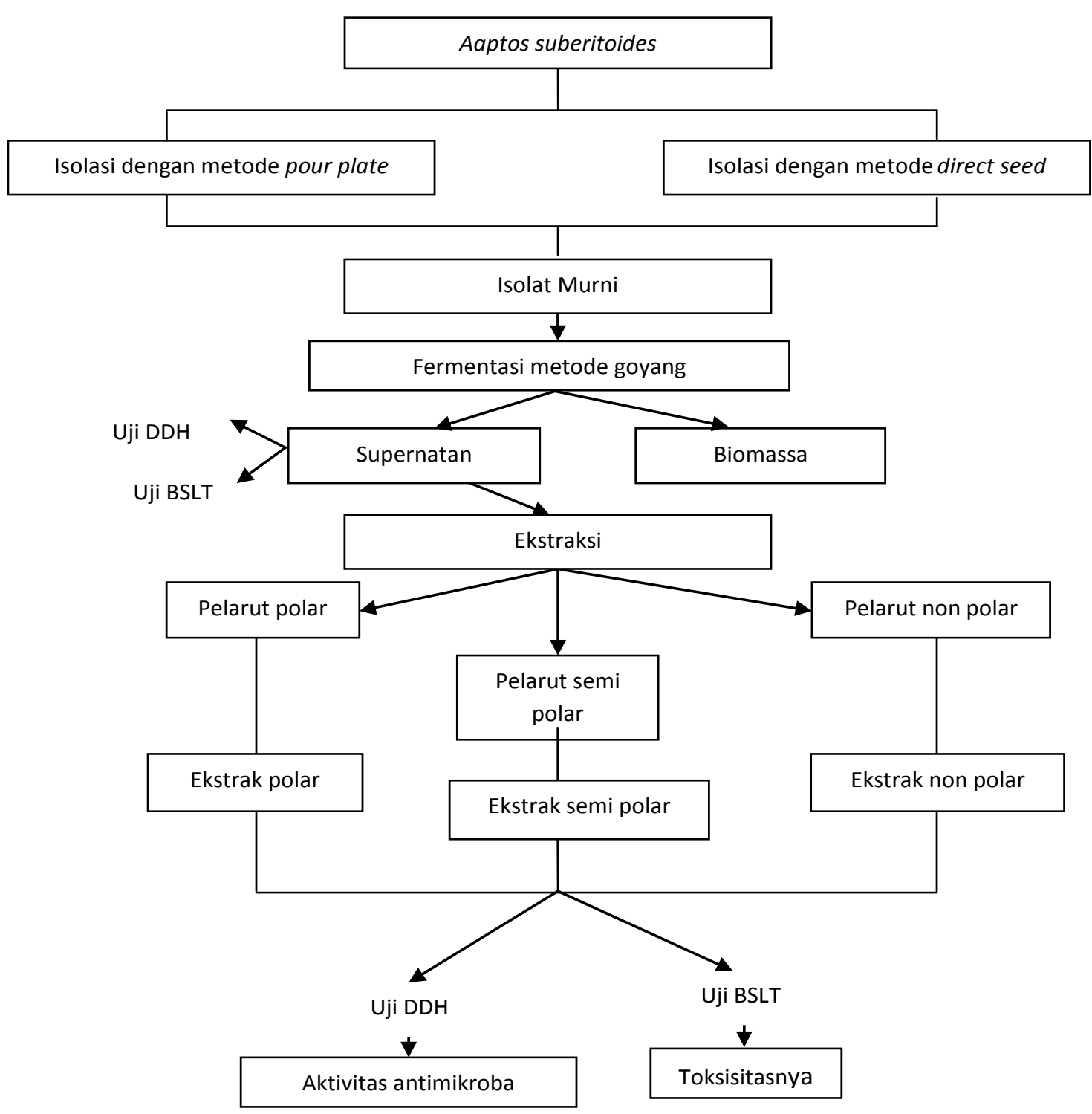

\section{HASIL DAN PEMBAHASAN}

\section{Hasil uji antimikroba}

Uji aktivitas antimikroba terhadap supernatan hasil fermentasi dari 8 (delapan) isolat menggunakan starter 10\% dan 50\% memiliki DDH lebih besar dibandingkan dengan ekstrak hasil partisi yaitu berkisar antara $6,67 \mathrm{~mm}-9,67 \mathrm{~mm}$ untuk mikroba uji bakteri dan 6,88 - 13,42 mm untuk mikroba uji fungi.

\section{Hasil uji aktivitas biologi secara BSLT}

Hasil uji BSLT nilai LC L $_{50}$ menggunakan starter $10 \%$ berkisar antara 518,192 $\mu \mathrm{g} / \mathrm{mL}-913,901 \mu \mathrm{g} / \mathrm{mL}$ dan starter $50 \%$ berkisar antara 333,960 $\mu \mathrm{g} / \mathrm{mL}-787,360 \mu \mathrm{g} / \mathrm{mL}$, 
sedangkan ekstrak $n$-heksan dan ekstrak air nilai $\mathrm{LC}_{50}$ antara $30 \mu \mathrm{g} / \mathrm{mL}-1000 \mu \mathrm{g} / \mathrm{mL}$ serta ekstrak etil asetat memiliki nilai $\mathrm{LC}_{50}<30 \mu \mathrm{g} / \mathrm{mL}$.

\section{KESIMPULAN}

1.Isolat metode direct seed berjumlah 3 isolat sedangkan isolat pour plate berjumlah 5 isolat, sehingga isolat berjumlah 8 (delapan).

2.Berdasarkan hasil uji aktivitas antimikroba supernatan hasil fermentasi goyang memiliki DDH yang lebih besar dibandingkan ekstrak hasil partisi, dari hasil uji BSLT nilai LC 50 supernatan lebih tinggi dari ekstrak $n$-heksan dan air yang sama-sama termasuk kategori toksik sedangkan untuk ekstrak etil asetat termasuk dalam kategori sangat toksik.

\section{DAFTAR PUSTAKA}

1. Suparno. Kajian Bioaktif Spons Laut (Porifera: Demospongiae) Suatu Peluang Alternatif Pemanfaatan Ekosistem Karang Indonesia Dalam Bidang Farmasi. Makalah Pribadi Falsafah Sains (PPs 7002), 2005.

2. Fajarningsih ND et al. Potensi Antitumor Ekstrak Spons Crella papilata Asal Taman Nasional Laut Kepulauan Seribu. Jurnal Pascapanen dan Bioteknologi Kelautan dan Perikanan 2006 ; 1 (1). 